\title{
Conflicting logics for crisis management in tourism
}

\section{Christina Öberg}

\begin{abstract}
Purpose - In tourism research, crisis management mostly refers to operational, on-location, chaotic measures taken as a crisis strikes a tourism destination. Related to COVID-19, this paper focuses on public initiatives representing strategic-oriented crisis management while showing that such initiatives may not help those needing support. More precisely, the paper discusses and exemplifies the conflict of logics between private sector interests and public initiatives related to crisis management in tourism.
\end{abstract}

Design/methodology/approach - The main data source is a structured newspaper review of COVID-19 and tourism as covered in the Swedish press, comprising more than 4,000 items.

Findings - Findings indicate logics manifested at different levels and a logic gap between small and large firms. Large firms are potentially better able to adapt but tend to wait passively for financial support rather than reformulate their business operations.

Originality/value - The paper contributes to research on crisis management in tourism by taking a public, societal-level view of crisis management juxtaposed against the local actors' sphere of operations. The conflict of logics proves how support needs to be improved to better help a sector in crisis. Thematic logics are introduced as a concept and captured in the conflicts between the present and the future, survival and change and operations and aggregates in crisis management. Broadly, the paper provides valuable insights into the future of tourism while indicating policy failures in the sector.

Keywords COVID-19, Crisis, Logic, Pandemic, Private/public, Tourism

Paper type Research paper

\section{Introduction}

The tourism sector comprises large firms operating as travel, accommodation and entertainment providers and many small entrepreneurs producing various local offerings (Linton and Öberg, 2020). Private initiatives are fundamental for tourism and endorsed as good ways to create business and growth, especially in geographical areas with limited opportunities (Chi and Qu, 2008). Crises, such as the COVID-19 outbreak in 2019/2020 (Radic et al., 2020), have harmed most parts of the tourism sector, potentially over the long term: Travel bans disrupt most operations (Gossling et al., 2020; Hall et al., 2020) and recession generally affects tourism negatively (Papatheodorou et al., 2010). While tourism operations rely primarily on private initiatives to stay afloat, such crises call for public support.

The public support focuses on how the sector might operate in future, including broad initiatives to develop relevant competencies to generate employment (Martin and Scott, 2000; Audretsch, 2004) with less emphasis on individual firms. The private entrepreneurs focus on staying in business, with entrepreneurial initiatives possibly leading to a (temporary) refocus of operations. This gives rise to a potential conflict of logics (Greenwood et al., 2010) between, on the one hand, entrepreneurial firms' sudden requests for public support and, on the other, how public support albeit intended to support business life, would not necessarily help individual entrepreneurs.
Christina Öberg is based at the CTF Service Research Center, Karlstad University, Karlstad, Sweden and The Ratio Institute, Stockholm, Sweden.

Received 31 October 2020 Revised 14 February 2021 20 April 2021

Accepted 25 April 2021

() Christina Öberg. Published in Journal of Tourism Futures. Published by Emerald Publishing Limited. This article is published under the Creative Commons Attribution (CC BY 4.0) licence. Anyone may reproduce, distribute, translate and create derivative works of this article (for both commercial and non-commercial purposes), subject to full attribution to the original publication and authors. The full terms of this licence may be seen at http://creativecommons. org/licences/by/4.0/legalcode 
In light of the COVID-19 crisis, this paper conceptually discusses such a conflict of logics in crisis management while highlighting the issue using empirical examples from tourism. The purpose of the paper is to discuss and exemplify the conflict of logics between private sector interests and public initiatives related to crisis management in tourism. The following research questions are addressed:

1. What conflicts of logic have emerged as the consequence of attempted crisis management?

\section{How can they be understood in terms of representations?}

The paper contributes to previous research by addressing the conflict of logics related to crisis management in tourism. To date, research has concentrated on the effects of the COVID-19 pandemic on tourism (Farzanegan et al., 2021) and how it is transforming the sector (Gossling et al., 2020; Hall et al., 2020) now and beyond the pandemic (Assaf and Scuderi, 2020; Brouder et al., 2020). However, as indicated by the Journal of Tourism Futures special issue call, less is known about strategic-oriented crisis management related to the crisis. With most research describing COVID-19 and its consequences in specific regions, theorizing related to the crisis remains limited (Cohen and Cohen, 2012; Nasir et al., 2020). Zenker and Kock (2020) call for more structured and integrated approaches to studying tourism related to COVID-19, which aligns with how this paper illuminates the broader questions of public support logic, conflicts in orientation to tourism, crisis management related to conflicts of logic and how attempts to manage a crisis can actually exacerbate it. Research focusing on public support in tourism remains rare (Dredge and Jamal, 2015; Shao et al., 2021). Addressing the tourism crisis from the perspective of parties' logics is a response not only to the call for more interdisciplinary research related to COVID-19 (Wen et al., 2020) but also to the present special issue call that highlights the risk of overlooking policy failures and structural issues. Moreover, this allows to indicate how the structure itself may lead to remedies that, worst case, actually intensify a crisis. Theoretically, the paper contributes to research on crisis management in tourism (Mair et al., 2016) by taking a societal (public)-level view of a crisis juxtaposed against the local actors' sphere of operations. More precisely, the paper introduces the concept of thematic logics in crisis management and portrays it as conflicts between the present and the future, survival and change, and operations and aggregates. This theorizing contributes to research on crises beyond the current COVID-19 crisis in tourism. The conflict of logics manifests as contradictory forces, proving how public support and the expectations around it may need to be improved to better support a sector in crisis.

The paper is structured as follows: A brief overview of crises and crisis management in tourism follows this introduction. Next, the theoretical framing of logics is introduced. The research design follows thereafter. The empirical part of the paper is based on analyses of news items, and the findings are subsequently summarized and analyzed. The paper ends with conclusions, managerial and theoretical contributions and ideas for further research.

\section{Context: crisis management in tourism}

"Crisis" in tourism research refers to any sudden, unplanned disruption causing negative effects on the number of tourists or tourism income at a destination (Blake and Sinclair, 2003; Hall, 2010). Typically, the management of such crises would be local, acute and a matter of reducing risks to life or nature. Prior to the COVID-19 pandemic (Radic et al., 2020), research on structured or strategic crisis or disaster management in tourism is limited (Faulkner, 2001). The literature tends to focus on the effects of natural disasters or political turmoil on tourism destinations (Saha and Yap, 2014) and the operational handling of such disruptions as they occurred, which is mostly described as chaotic, unstructured management in the eye of the crisis (Sonmez, 1998; Ritchie, 2004). Summarizing previous research on crisis management in tourism, Mair et al. (2016) exemplify such topics as lack

of communication among stakeholders, sensationalism in the media, ineffective marketing 
messages, poor management, damage to destination image and reputation and changes in tourism behavior as post-crises effects. Hystad and Keller (2008) refer to the steps of preparedness, response and recovery in tourism crisis management, while Ritchie (2008) describes reduction and readiness as means to provide a more organized approach to crisis management in tourism. Moreover, there are attempts to integrate tourism research with crisis management from the broader organizational management literature to provide a structured, pro-active orientation to crises, highlighting the variation in the conceptualization of crises (Papatheodorou et al., 2010).

Following Papatheodorou et al. (2010), and for the topic of this paper, the question of what kind of crisis COVID-19 represents for tourism deserves some attention. While being perceived as sudden, the crisis itself could be defined as long term, with new consequences emerging as the COVID-19 virus continues to spread. The crisis is global rather than local, while local (national) responses may themselves cause additional crises and/or deepen or reduce its effects which, ultimately, makes it difficult to determine the causes and the consequences. For tourism, the effects of the crisis would mostly have emerged as a consequence of the handling of the pandemic in terms of travel bans, restrictions on the number of people simultaneously visiting restaurants, exhibitions or other types of events, and potentially long-term paradigm shifts in how we travel. As a cause of the crisis manifested in tourism, the handling of the pandemic-together with the mental effects on consumers' notion of traveling - means that the suddenness of the crisis (Blake and Sinclair, 2003; Hall, 2010) is partly replaced by continuous new causal drivers that, while affecting large portions of the tourism sector, would be unequally distributed among destinations, types of operations and individual firms.

Although some studies have dealt with crises in tourism related to pandemics prior to COVID-19-Wang (2009), using examples including the SARS outbreak in Taiwan in 2003, points at how such crises reduce the number of tourists in a country, and Kuo et al. (2008) draw similar conclusions for avian flu and SARS in Asia-most of what we know about the impacts of a pandemic on tourism is found in more recent studies (Assaf and Scuderi, 2020; Brouder et al., 2020), leaving many questions unanswered.

\section{Theoretical framework: logic}

"Logic" refers to symbols and practices demonstrating assumptions, values and beliefs through which individuals create an understanding of their daily activities (Friedland and Alford, 1991; Thornton and Ocasio, 1999), making individuals consider their way of acting as rational. Logics therefore comprise preferences and influence behaviors. Meanwhile, and in the shaping and manifesting of logics, individuals share logics and make sense of each other's practices through shared belief systems. As such, logics should be collectively understood: Multiple parties may adhere to a logic, which influences their behavior and guides them through social constructs.

The dynamic character of logics indicates how they are challenged and change over time (Lounsbury, 2002). In the conceptualization of logics, researchers have taken the position that either there is a dominant logic that changes as society develops, or that various parties represent different logics which challenge each other. This leads to the assumption that there is a hierarchy of logics (Marquis and Tilcsik, 2013; Geissinger et al., 2019). For example, researchers refer to institutional orders to define the meta-level logics of markets, states and religions (Thornton et al., 2012); field-level logics describe the logics of, for instance, a group of individuals or an industry sector (Nigam and Ocasio, 2010) and microlevel logics represent not only a firm or multiple actors existing under similar conditions (Besharov and Smith, 2014) but also situation-specific cores, that is, including specific people or organizations as well as areas of foci or situations. 
Together, and acknowledging that meta-, field- and micro-level logics may exist simultaneously, logics may be described as competing, co-existing, hybrids or bricolages. Here, the potential for conflict among logics comes to the fore (Greenwood et al., 2010) where competing logics implies that representatives of one logic try to make their logic the dominant one. Co-existing logics would allow for individuals to switch among logics. Hybrid logics refers to the bridging of logics, constructing a new, combined logic. Bricolage, lastly, means that individuals combine aspects from various logics to a micro-level logic entailing partly shared, partly different and potentially opposing logics.

Identifying conflicts of logic does not mean that this paper addresses how to solve issues related to crisis management in tourism per se, rather that it illuminates an area that, if neglected, would increase the risk that attempts to solve a crisis would only compound the situation or lead to problems being left unsolved. This makes it important to ask: What conflicts of logic have emerged as the consequence of attempted crisis management? How can they be understood in terms of representation?

\section{Methods}

\section{Data capturing method}

The empirical part of this paper is based on a structured newspaper review complemented with opinion from the tourism and public sector at a seminar on tourism in Sweden, which was the inspiration to write this paper. The newspaper review examines items published in the Swedish press. Although Sweden has taken a different approach to the lockdown experienced in most countries, the tourism industry has still been hit hard. By keeping businesses running - the Swedish approach to COVID-19-the country shows some early consequences of the crisis that other countries may experience later, and it therefore represents an interesting context in which to study crisis management in tourism. A few previous studies related to COVID-19 have used data from the media (Chen et al., 2020; Shao et al., 2021), but these concern other regions of the world and raise different issues.

Published media data-all textual and online published media (including radio and TV broadcasts) from the major national and local Swedish newspapers and media houseswas drawn from a database (Business Retriever) over the period 2019-2020 to capture the COVID-19 outbreak to date. The last update of the review was conducted on October 30th, 2020. The following initial search string was used (translated from Swedish): ("tourism" or "tourist") and ("covid" or "corona") followed by the second search string "hospitality" and ("covid" or "corona"). The search for "covid" would include any reference to COVID-19, and various word combinations were tested to create a meaningful result for, and capturing content related to, the topic of this paper.

The first ("tourism") search resulted in 3,123 newspaper items, representing short pieces to editorial features, with single items distributed over the period 2019 to January 2020 to a peak in the period May to July with an average of about 500 items per month. The remaining months from March 2020 onwards produced about 300 items per month. The second search ("hospitality") produced 1,187 items, with a peak from March to June 2020 (approximately 200 items per month).

Newspaper items as a data source have their benefits and weaknesses. One of the claimed benefits is how they allow for capturing data at the time that events occurred (Huber and Power, 1985). Another benefit is how newspaper reviews effectively manage to capture and systematize a large amount of data encompassing multiple perspectives (Öberg, 2009). As the research was conducted during the COVID-19 pandemic, newspaper reviews provided empirical data that would have been difficult to capture from face-to-face meetings. That said, one of the weaknesses of capturing data from media sources is that journalists or

editors are inevitably biased toward the extreme rather than the average. Moreover, as 
more and more newspaper items re-report directly from, for instance, firms' press releases, newspaper items would be biased by the senders' viewpoint.

\section{Data analysis}

To analyze the data, newspaper items were first categorized into a grid describing on the one hand the parties and, on the other, their activities and experienced consequences. The parties were categorized as: tourism firms (travel agencies, accommodation providers, exhibitions, museums, other tourist attractions and entertainment organizers), parties representing the public (municipal or state-level initiatives) or funds for business support, and based on their size of operations and geographical coverage (local, national, global). This allowed to compare the perspectives and logics of the various parties. Text items were incorporated into the grid and compared within each dimension to establish empirical codes (Gioia and Pitre, 1990). They were subsequently condensed by comparisons among text items, while remaining connected with the raw material and publishing date for traceability and the ability to construct a timeline of development. To give voice to the parties involved, the analysis favored direct quotations to avoid media bias as much as possible. Together, this provided a content-oriented coding structure (Krippendorff, 2004) where the descriptive codes were iterated from the documents and reduced in a number of processual steps (Pratt, 2009). Aggregated codes within each cell of the grid were then compared across perspectives to help capture conflicts of logic in activities and experiences and to relate these to (characteristics of) parties. This comparison among perspectives based on rationales behind activities and experiences enabled the identification of various dimensional conflicts of logics described as thematical logics between the present and the future, survival and change and operations and aggregates. The findings are presented below in a timeline narrative with direct (translated) quotations from the newspaper items to illustrate points, while the different perspectives and characteristics are noted throughout. Central to the analysis is identification of not only the types of logic conflicts that emerged over the data capturing period but also the parties that represented the various logics.

\section{Findings}

The typical tourism firm, at least in the northern part of Europe, operates cyclically, that is, its business is highly dependent on the seasons. This means that it has in its DNA the need to cope with a low season while seeking to exploit business during the high season, or that it strikes a balance between tourists and business people, or tourists and locals as its customers.

As COVID-19 started to really affect businesses in March 2020, attention was focused early on the Swedish tourism sector as traveling restrictions emerged on the agenda. In early March, this affected foreign visitors to events and delegates planning to attend foreign trade fairs. However, by mid-March, claims were already being made about a downturn in the economy such that several tourism firms and event companies announced their intention to lay off staff, despite them operating locally and/or marketing to business people to offset low demand for leisure tourism. For example, large companies commonly took precautions or used the crisis to solve financial issues that had occurred before. They appeared to be driven by a logic of "if we do not get paid, we'll cancel," which was evident in the cancelation of sports events and tournaments.

Meanwhile, representatives of the public sector pointed out the potential opportunities of the crisis, as captured in the following quotation: "This has positive consequences for the staycation. Rather than traveling abroad, people will have a vacation at home once everything has settled down. If an event is canceled, there are alternative activities" (Norrköpings Tidningar, March 14th, 2020). In contrast, representatives of the private sector held a less optimistic view: "It is like a horror movie. It's pitch black, not least for hospitality. The business cycle has jumped on its brakes, and COVID is escalating fast." Around the 
same time, calls were being made for a crisis fund, while the news reported on how predominantly small companies were trying to help one another.

Public intervention followed in the form of postponed tax payments and, later, temporary reductions in employer taxes. Loans were introduced but, from the viewpoint of small firms, they appeared to favor only larger firms: "Why introduce an expense loan? This is a really bad proposition" (Länstidningen Södertälje, March 23rd, 2020). Small firms that were not eligible for these loans, reached out to their customers, begging them to continue buying their products and using their services, while asking for support through a fund providing seed money. Hence, small firms focused on remaining in business at any price, eventually meaning that they tried to challenge the broad-brush restrictions imposed across society.

A tourism governance association introduced support for training to help tourism firms adapt their operations, the idea being to help firms in crisis prepare themselves for the postpandemic future by developing their workforce competencies: "The education will help them keep staff and be prepared for better days" (GöteborgDirekt, March 28th, 2020). Meanwhile, firms described how they needed immediate support as the number of bankruptcies rose, while municipal representatives continued to argue that the summer would bring an upturn for businesses (April 7th, 2020). As noted by an entrepreneur in the tourism sector: "There is a crisis package, but it is of no use in this sector. It does not matter if you reduce employer tax if you have no income. The crisis intervention is truly standardized ... Laying off staff is not a solution since the firms pay for this in the short term ... it is the lack of cash that breaks firms" (Falköpings Tidning, April 9th, 2020).

The government tried to conceive various ways of keeping the economy running more generally, which meant that certain parts of the tourism sector experienced partial relief while others felt that government initiatives were unfair (April 23rd, 2020). The month of May came, and those representing both the public sector and the tourism industry had high expectations for the summer. However, further travel bans were imposed within Sweden and limits were placed on the number of people allowed to congregate in one place. Shortly afterwards, local events including concerts and exhibitions were canceled (May 7th, 2020). Since Sweden had decided to keep the economy running, foreign countries' respective bans on travel to Sweden over the summer significantly reduced the number of customers in the tourism sector. Private and public sector spokespeople continued to disagree: "For the firms in the tourism sector, this is a catastrophe" (private firm) versus "In the wait for the record summers of 2021 and 2022, creativity should generate new solutions" (public sector representative) (GotlandsAllehanda, May 9th, 2020).

Small firms operating locally tried to change their business models, focusing on residents rather than tourists, concluding that it was a matter of survival rather than profits (May 23rd, 2020). This meant that, among other things, they withheld their salaries to remain in business. Governmental support was increasingly directed at the sector (May 26th, 2020), while the focus continued to be on providing training for laid-off staff and enhancing competencies while firms struggled to survive. Hence, the focus was on preparing firms for the post-crisis future rather than helping them survive the crisis (June 1st, 2020). In early June, some national travel bans were lifted for the summer, and initiatives were introduced to promote safe traveling and tourism. A restriction of 50 people congregating in one place was maintained and monetary support started to be directed at the sector, including municipal tourism organizations. Museums opened up while events continued to be canceled. Public sector support continued to be directed partially at education and partially at life after COVID-19: "Make Sweden a need-to-go-there destination for foreign visitors. It is about being innovative, daring and progressive in the communication" (Besöksliv, July 2nd, 2020).

In August, it was reported how Swedish residents had not only spent their vacations at home, visiting attractive destinations in Sweden, but also how they had disregarded restrictions. In an effort to avoid the anticipated crowds, more Swedes than normal traveled 
to the mountains, but this only led to overcrowding in those areas. Some tourism companies tried to refocus operations to provide events online or take extra precautions in delivering their services. Overall, the number of COVID cases in Sweden declined over the summer season. Nevertheless, companies continued to go bankrupt and it was clear that the crisis was not over (August 20th, 2020).

As the autumn arrived, the prospect of a new wave of COVID infections presented itself. Meanwhile, media reported on the summer-its losers and winners (October 6th, 2020) - and a notion of "the new normal" ( $T T$, October 8th, 2020) was introduced to claim how tourism patterns had changed and how the tourism sector had shrunk: "We will continue to travel, but not as before. For those daring or being able to see the new horizon, there is the potential for a new future," reported a public sector representative ( $T$, October 8th, 2020). Increasingly, the focus was on monetary support, while the tourism firms asked for fewer restrictions, especially the limitation on how many individuals could meet in one place at the same time.

As this is written, a new wave of COVID infections is being reported, with several city areas in Sweden going into lockdown, and any easing of restrictions has ended. Meanwhile, October is by no means a popular tourist season in Sweden.

\section{Discussion}

As the findings section indicates, there are differences between how various parties make sense of the COVID-19 crisis and how they believe it should be managed (Hystad and Keller, 2008; Ritchie, 2008), which conveys different-and indeed conflicting-logics between parties (Friedland and Alford, 1991; Thornton and Ocasio, 1999; Besharov and Smith, 2014). More precisely, the findings point out a number of conflicts, which are dominated by the conflict between the private and the public sectors, but where certain groups of private firms may adhere to the public sector logic.

Looking first at private firms, these are focused on handling the present, surviving and, as the crisis evolves, redefining their business models. The tourism sector, though, is diverse in terms of those firms operating within it (Linton and Öberg, 2020). Among the private firms, there is a logic gap between small and large firms. Large firms are potentially better able to adapt but tend to wait passively for financial support rather than reformulate their business operations, which could be seen in how many of them canceled their operations or events before the crisis had really taken hold. The "if we do not get paid, we'll cancel" logic was evident among these firms from the early stages of the pandemic. However, as the crisis developed a shift could be seen among all firms-but especially small ones-from going it alone to demanding public sector support (Webster and Ivanov, 2016), something that the large firms claimed right from the start.

As for the public organizations, they first focused on identifying opportunities arising from the crisis for the sector as a whole rather than its individual firms. From the start they believed that tourism would fuel the sector and create new opportunities (such as the staycation) within it. Later, support came in the form of reducing financial burdens for firms across all sectors but following the logic of large firms (e.g., the reduction in taxes and the launching of loans). Thereafter, the public sector engaged in the refocusing of operations, promoting the idea of the crisis as an engine of entrepreneurship and talking about the future and the post-COVID situation. Education and competence development were seen as routes to the future, and the public sector thereby followed a logic that disregarded the crisis in the short term by focusing on the time after it, both in terms of talking about next year's summer and the proposed educational initiatives rather than urgent and immediate interventions. In turn, this meant that those most desperately needing support would not receive it, and much of the support was indeed directed at large firms or even public organizations operating in the tourism sector.

To summarize, three types of conflicts of logic can be found: a time-based logic of operating in the present or the future, an entrepreneurship logic as a conflict between survival and change and an aggregation-level logic describing the conflict of seeing 
operations as individual firms or aggregates. These can be described as thematic logics. The public here represents the future, change and aggregation, while the private tourist companies describe the present, survival and individual firm logic. There is, though, a difference in the first type of logic between large and small firms: Large private firms acted as if the future were now (pre-acting), while small firms acted in the present, and support was directed at the future, reflecting the large-firm logic. The reason for the public sector acting for the future, change and the collective aggregate is rooted in the political scene with complex decision processes based on amalgamated statistics, along with a dialogue with large firms. Small private firms shifted in their logics as their operations were increasingly challenged, but they remained focused on keeping their operations afloat, often beyond financial sense.

If we relate the above to how Besharov and Smith (2014) describe how various logics may be present simultaneously as competing, co-existing, hybrid and a bricolage of logics, then we can see that various logics indeed exist simultaneously, but thus carry strong competing-or conflicting - components. Between the private and the public sectors, logics would be competing, with both parties trying to make their logic the dominant one: Private firms try to attract public sector support to fit their needs, while the public sector attempts to promote its opportunity, future-oriented logic to dominate everyone's view. The private tourism sector being quite heterogeneous (types of operations, sizes and geographical coverage) means that it, in turn, represents a bricolage of logics. The bricolage means that conflicts may appear for certain types of private firms and not for others, and there is the suggested partial bridging of logics between public sector initiatives and large, locally operating firms at the expense of small firms that depend on income from their high-season business activities.

\section{Conclusion}

This paper discusses and exemplifies the conflict of logics between private sector interests and public initiatives related to crisis management in tourism. The introduction asked: What conflicts of logic have emerged as the consequence of attempted crisis management? How can they be understood in terms of representations? As for the conflicts of logic, these are demonstrated as conflicts of time, conflicts between survival and change and conflicts of aggregation levels. The representations could partly be seen as an in-group logic (where tourism firms call for immediate intervention and measures to help individual firms survive) and an out-group logic (where the public sector considers the future of the whole sector without realizing the immediacy of the emergency for certain firms). Meanwhile, there is a difference between small and large firms with large firms acting as if the future were now while small firms act in the present where, as the situation deteriorates, their behaviors change over time.

\section{Theoretical contributions}

The main contribution of this paper is how it theorizes (cf. Van De Ven and Scott Pole, 1995) conflicting logics related to crisis management. More specifically, the paper introduces how conflicts of logic may be built up by multiple conflicting components with thematic logics as a new concept introduced to the literature, describing how logics are related to specific components defined by the situation. In the COVID-19 crisis, the themes represent a timebased logic of operating in the present or the future, an entrepreneurship logic as a conflict between survival and change, and an aggregation-level logic describing the conflict of seeing operations as individual firms or aggregates. For entrepreneurs there is also the conflict of "self" in terms of needing to rely on support, having previously based their operations on a "going it alone" logic. The breaking down of conflicts into components of conflicting logics per se (i.e., thematic logics as part of a field-level logic, Nigam and Ocasio, 2010), rather than the components identified here would constitute this paper's theoretical contribution. 
Related to the special issue call, this paper shows that establishing precisely how COVID19 affects tourism is a matter of perspective, where it is difficult not only to identify causes but also to rationalize how well-intentioned interventions may in fact exacerbate the crisis. While highlighting policy failures and the risk of diverting attention to the wrong cause, conflicts of logic indicate how the future itself conflicts with the present.

\section{Managerial implications}

This paper exposes an important issue related to crisis support, which has consequences for management of private tourism firms and public sector representatives. The identified conflicts of logic show that, while both private firms and public initiatives aim to diminish the impacts of the COVID-19 crisis, they do not address or understand the same needs. Communication would be a key factor, where it is important that those responsible for supporting the firms (i.e., public initiatives) listen to the needs of private firms. In such communication, it would be important to include perspectives of both the present and the future, but where the future can never overshadow present needs for survival. Moreover, it would be important to address the passiveness of "giving up" and try to turn it into action plans. For managers, it would be important to emphasize their short-term issues and, for instance, establish interest groups to advocate their situation. As seen among many firms during the COVID-19 crisis, a solid financial foundation is essential to withstand the test of any crisis.

\section{Ideas for further research}

This paper opens up an opportunity for further research in theorizing crisis management in tourism (Cohen and Cohen, 2012; Nasir et al., 2020; Zenker and Kock, 2020). More precisely, the paper reaches beyond a purely descriptive account of a crisis and integrates it with a well-known perspective from organizational studies. Exploring further such integrations and elaborating on conflicting logics related to crises specifically may prove to be fruitful routes for future research. The conflict components identified in this paper could well be tested in contexts beyond tourism and crises, or at least contexts related to other tourism crises. The latter option may, like the present paper, entail newspaper and media reviews of previous crises and comparisons among various types of crises.

The COVID-19 crisis will likely attract further research interest. Regarding the conclusions this paper makes, it would be interesting to study crisis management in different geographical areas to identify and understand the range of interventions made to address the pandemic. It would also be interesting to follow the situation in Sweden to see whether management of the crisis changes over time and whether conflicting logics ultimately converge or continue to develop in opposing directions.

\section{References}

Assaf, A. and Scuderi, R. (2020), "COVID-19 and the recovery of the tourism industry", Tourism Economics, Vol. 26 No. 5, pp. 731-733.

Audretsch, D.B. (2004), "Sustaining innovation and growth: public policy support for entrepreneurship", Industry and Innovation, Vol. 11 No. 3, pp. 167-191.

Besharov, M.L. and Smith, W.K. (2014), "Multiple institutional logics in organizations: explaining their varied nature and implications", Academy of Management Review, Vol. 39 No. 3, pp. 364-381.

Blake, A. and Sinclair, M. (2003), "Tourism crisis management-US response to September 11", Annals of Tourism Research, Vol. 30 No. 4, pp. 813-832.

Brouder, P., Teoh, S., Salazar, N.B., Mostafanezhad, M., Pung, J.M., Lapointe, D., Desbiolles, D., Freya Haywood, M., Hall, C.M. and Clausen, H.B. (2020), "Reflections and discussions: tourism matters in the new normal post COVID-19", Tourism Geographies, Vol. 22 No. 3, pp. 735-746. 
Chen, H., Huang, X. and Li, Z. (2020), "A content analysis of Chinese news coverage on COVID-19 and tourism", Current Issues in Tourism, (forthcoming).

Chi, C.G.-Q. and Qu, H. (2008), "Examining the structural relationships of destination image, tourist satisfaction and destination loyalty: an integrated approach", Tourism Management, Vol. 29 No. 4, pp. 624-636.

Cohen, E. and Cohen, S.A. (2012), "Current sociological theories and issues in tourism", Annals of Tourism Research, Vol. 39 No. 4, pp. 2177-2202.

Dredge, D. and Jamal, T. (2015), "Progress in tourism planning and policy: a post-structural perspective on knowledge production", Tourism Management, Vol. 51, pp. 297-285.

Farzanegan, M.R., Gholipour, H.F., Feizi, M., Nunkoo, R. and Andargoli, A.E. (2021), "International tourism and outbreak of Coronavirus (COVID-19): a cross-country analysis", Journal of Travel Research, Vol. 60 No. 3, pp. 687-692

Faulkner, B. (2001), "Towards a framework for tourism disaster management", Tourism Management, Vol. 22 No. 2, pp. 135-147.

Friedland, R. and Alford, R. (1991), "Bringing society back", in Powell, W. and DiMaggio, P. (Eds), The New Institutionalism in Organizational Analysis, University of Chicago Press, Chicago, pp. 232-263.

Geissinger, A., Laurell, C., Öberg, C. and Sandström, C. (2019), "Tracking the institutional logics of the sharing economy", in Bardhi, F., Belk, R. and Eckhardt, G. (Eds), Handbook on the Sharing Economy, Edward Elgar, London.

Gioia, D.A. and Pitre, E. (1990), "Multiparadigm perspectives on theory building", Academy of Management Review, Vol. 15 No. 4, pp. 584-602.

Gossling, S., Scott, D. and Hall, C.M. (2020), "Pandemics, tourism and global change: a rapid assessment of COVID-19", Journal of Sustainable Tourism, Vol. 29 No. 1, pp. 1-20.

Greenwood, R., Díaz, A.M., Li, S.X. and Lorente, J.C. (2010), "The multiplicity of institutional logics and the heterogeneity of organizational responses", Organization Science, Vol. 21 No. 2, pp. 521-539.

Hall, C.M., Scott, D. and Gossling, S. (2020), "Pandemics, transformations and tourism: be careful what you wish for", Tourism Geographies, Vol. 22 No. 3, pp. 577-598.

Hall, C.M. (2010), "Crisis events in tourism: subjects of crisis in tourism", Current Issues in Tourism, Vol. 13 No. 4, pp. 401-417.

Huber, G.P. and Power, D.J. (1985), "Retrospective reports of strategic-level managers: guidelines for increasing their accuracy", Strategic Management Journal, Vol. 6 No. 2, pp. 171-180.

Hystad, P.W. and Keller, P.C. (2008), "Towards a destination tourism disaster management framework: long-term lessons from a forest fire disaster”, Tourism Management, Vol. 29 No. 1, pp. 151-162.

Krippendorff, K. (2004), Content Analysis: An Introduction to its Methodology, Sage, Thousand Oaks.

Kuo, H.I., Chen, C.C., Tseng, W.C., Ju, L.F. and Huang, B.W. (2008), "Assessing impacts of SARS and Avian Flu on international tourism demand to Asia”, Tourism Management, Vol. 29 No. 5, pp. 917-928.

Linton, G. and Öberg, C. (2020), "A conceptual development of a business model typology in tourism: the impact of digitalization and location”, TIM Review, Vol. 10 No. 7, pp. 17-28.

Lounsbury, M. (2002), "Institutional transformation and status mobility: the professionalization of the field of finance", Academy of Management Journal, Vol. 45, pp. 255-266.

Mair, J., Ritchie, B.W. and Walters, G. (2016), "Towards a research agenda for post-disaster and postcrisis recovery strategies for tourist destinations: a narrative review", Current Issues in Tourism, Vol. 19 No. 1, pp. 1-26.

Marquis, C. and Tilcsik, A. (2013), "Imprinting: toward a multilevel theory", Academy of Management Annals, Vol. 71, pp. 195-245.

Martin, S. and Scott, J.T. (2000), "The nature of innovation market failure and the design of public support for private innovation", Research Policy, Vol. 29, pp. 437-447.

Nasir, A., Shaukat, K., Hameed, I.A., Luo, S., Mahboob, T. and lqbal, F. (2020), "A bibliometric analysis of Corona pandemic in social sciences: a review of influential aspects and conceptual structure", IEEE Access, Vol. 8, pp. 133377-133402. 
Nigam, A. and Ocasio, W. (2010), "Event attention, environmental sensemaking, and change in institutional logics: an inductive analysis of the effects of public attention to Clinton's Health Care Reform Initiative", Organization Science, Vol. 21 No. 4, pp. 823-841.

Öberg, C. (2009), "Hårda fakta och mjuka värden-Årsredovisningar som underutnyttjad källa för studier av dynamik i affärsrelationer", Nordiske OrganisasjonsStudier, Vol. 4, pp. 71-93.

Papatheodorou, A., Rossello, J. and Xiao, H. (2010), "Global economic crisis and tourism: consequences and perspectives", Journal of Travel Research, Vol. 49 No. 1, pp. 39-45.

Pratt, M.G. (2009), "For the lack of boilerplate: tips on writing up (and reviewing) qualitative research", Academy of Management Journal, Vol. 52 No. 5, pp. 856-862.

Radic, A., Law, R., Luck, M., Kang, H., Ariza-Montes, A., Arjona-Fuentes, J.M. and Han, H. (2020), "Apocalypse now or overreaction to Coronavirus: the global cruise tourism industry crisis", Sustainability, Vol. 12 No. 17, pp. 1-19.

Ritchie, B. (2004), "Chaos, crises and disasters: a strategic approach to crisis management in the tourism industry”, Tourism Management, Vol. 25 No. 6, pp. 669-683.

Ritchie, B. (2008), "Tourism disaster planning and management: from response and recovery to reduction and readiness", Current Issues in Tourism, Vol. 11 No. 4, pp. 315-348.

Saha, S. and Yap, G. (2014), "The moderation effects of political instability and terrorism on tourism development: a cross-country panel analysis”, Journal of Travel Research, Vol. 53 No. 4, pp. 509-521.

Shao, Y., Hu, Z., Luo, M., Huo, T. and Zhao, Q. (2021), "What is the policy focus for tourism recovery after the outbreak of COVID-19? A co-word analysis", Current Issues in Tourism, Vol. 24 No. 7, pp. 899-904.

Sonmez, S. (1998), "Tourism, terrorism, and political instability", Annals of Tourism Research, Vol. 25 No. 2, pp. 416-456.

Thornton, P.H. and Ocasio, W. (1999), "Institutional logics and the historical contingency of power in organizations: executive succession in the higher education publishing industry, 1958-1990", American Journal of Sociology, Vol. 105 No. 3, pp. 801-843.

Thornton, P.H., Ocasio, W. and Lounsbury, M. (2012), The Institutional Logics Perspective: A New Approach to Culture, Structure, and Process, Oxford University Press, Oxford.

Van De Ven, A.H. and Scott Pole, M. (1995), "Explaining development and change in organizations", Academy of Management Review, Vol. 20, pp. 510-540.

Wang, Y.-S. (2009), "The impact of crisis events and macroeconomic activity on Taiwan's international inbound tourism demand", Tourism Management, Vol. 30 No. 1, pp. 75-82.

Webster, C. and Ivanov, S. (2016), "Political ideologies as shapers of future tourism development", Journal of Tourism Futures, Vol. 2 No. 2, pp. 109-124.

Wen, J., Wang, W., Kozak, M., Liu, X. and Hou, H. (2020), "Many brains are better than one: the importance of interdisciplinary studies on COVID-19 in and beyond tourism", Tourism Recreation Research, Vol. 46 No. 2, pp. 310-313.

Zenker, S. and Kock, F. (2020), "The coronavirus pandemic - a critical discussion of a tourism research agenda", Tourism Management, Vol. 81, pp. 1-4.

\section{Corresponding author}

Christina Öberg can be contacted at: christina.oberg.se@gmail.com

For instructions on how to order reprints of this article, please visit our website: www.emeraldgrouppublishing.com/licensing/reprints.htm

Or contact us for further details: permissions@emeraldinsight.com 